\title{
Trikorhinofalangealt syndrom - klinisk presentasjon og genetikk
}

\begin{abstract}
Sammendrag
Bakgrunn. Trikorhinofalangealt syndrom (TRPS) er en arvelig, mild skjelettdysplasi med et karakteristisk klinisk bilde. Siden de typiske funnene kan være milde, forblir trolig mange pasienter udiagnostiserte. I denne artikkelen gis det en kort oversikt over tilstanden basert på egne erfaringer.
\end{abstract}

Materiale og metode. Vi har tatt utgangspunkt i fire pasientkasuistikker.

Resultater. Trikorhinofalangealt syndrom deles i type 1,2 og 3 , ut ifra fenotype og genotype. Alle våre pasienter har typiske ansiktstrekk, som stor nese og tynn overleppe, tynn hårvekst samt korte krokete fingre med karakteristiske røntgenologiske forandringer. Tilstanden arves autosomalt dominant og skyldes mutasjon i TRPS1-genet, som koder for et genregulerende protein av betydning for utviklingen av hår og modulering av kondrocytter. Diagnosen stilles oftest på klinisk grunnlag, men DNA-undersøkelse kan utføres ved tvil om diagnosen eller om typen. To av pasientene våre fikk stilt diagnosen ut fra kliniske og radiologiske funn, mens for de to andre ble det gjort genetiske undersøkelser i tillegg. Det finnes ingen kausal behandling, men diagnose kan gi forklaring på pasientens plager, og man kan tilby genetisk veiledning til pasient og familie. Ortopediske inngrep og kosmetiske hjelpemidler vil hjelpe mange.

Fortolkning. I en stadig mer teknifisert medisinsk hverdag er det kliniske blikket fortsatt det viktigste verktøyet for å stille diagnosen hos pasienter med denne tilstanden.

\section{Kristoffer M. Brodwall*}

kristoffer.brodwall@gmail.com

Barneavdelinga i Ålesund

Helse Sunnmøre

Pétur B. Júlíusson

Robert Bjerknes

Institutt for klinisk medisin

Seksjon for pediatri

Universitetet i Bergen

og

Seksjon for endokrinologi og metabolisme Barneklinikken

Haukeland universitetssykehus

\section{Randi Hovland}

Torunn Fiskerstrand

Senter for medisinsk genetikk

og molekylærmedisin

Haukeland universitetssykehus

\section{* Nåværende adresse:}

Barneklinikken

Haukeland universitetssykehus

Dersom man mistenker en udiagnostisert genetisk tilstand, kan det ofte være hensiktsmessig å rådføre seg med en genetiker. I utvalgte tilfeller vil det være indisert med genetisk testing for å bekrefte eller avkrefte diagnosen.

I 1966 beskrev Giedion (1) triaden sparsomt og langsomtvoksende hår (trix), pæreformet nese (rhis) og korte fingre (phalanges) under navnet trikorhinofalangealt syndrom (TRPS). Årsaken til tilstanden er tap av eller mutasjon i TRPS1-genet på kromosom $8(2,3)$. Forekomsten er dårlig kartlagt, men trolig er trikorhinofalangealt syndrom underdiagnostisert, fordi mange pasienter har beskjedne avvik. Tilstanden kan imidlertid ofte gjenkjennes kun ved å se på pasientens ansikt og fingre, mens genetiske undersøkelser kan være nyttig i tvilstilfeller. Dette illustreres med de følgende kasuistikkene.

\section{Materiale og metode}

I artikkelen tar vi utgangspunkt i fire kasuistikker. Målrettet kartlegging av kliniske og røntgenologiske trekk hos pasientene ga grunnlaget for de fleste vurderingene. Uavklarte spørsmål ble forsøkt besvart ved hjelp av kromosomundersøkelse og helgenomisk matriseundersøkelse.

\section{Kasuistikker}

Pasient 1

En jente ble ved femårsalderen henvist pga. kronisk hoste. Samtidig ble det nevnt at hun siden fødselen aldri hadde klippet håret, som likevel kun var 5-6 cm langt. Håret var lyst, dunaktig og svært tynt. Neglene hadde en tendens til å flise seg opp.

Gjennomgang av tidligere sykehistorie avdekket at jenta hadde blitt behandlet for mulig hoftedysplasi som spedbarn, at hun hadde hatt fotfeilstilling og at hun tidligere hadde så mobile ledd at man en periode ga henne diagnosen Ehlers-Danlos' syndrom. Undersøkelsen avdekket pæreformet nese, smale øyebryn (særlig lateralt), langt philtrum og tynn overleppe (fig 1), noe kort og bred nakke, korte og relativt tykke fingre.

Grunnet mistanke om trikorhinofalangealt syndrom ble det tatt røntgenbilder av hendene, som viste korte falanger og kjegleformede epifyser. Røntgenundersøkelsene viste også forsinket skjelettmodning, svarende til 3,5 år. Pasientens høyde lå omtrent på 10prosentilen, mens midtforeldrehøyden var inærheten av 97,5-prosentilen. Kognitiv, sosial og øvrig utvikling var aldersadekvat.

Kromosomanalyse viste normal, kvinnelig karyotype, 46,XX. Basert på de kliniske og radiologiske funnene kunne man stille diagnosen trikorhinofalangealt syndrom, og DNA-analyse ble derfor ikke oppfattet som nødvendig. Tilstanden ble funnet forenlig med type l og er trolig nyoppstått, siden man ikke fant grunnlag for à stille diagnosen hos foreldrene. Hårveksten ble av pasienten og hennes pårørende opplevd som det største problemet.

\section{Pasient 2}

En jente hadde fra 6-7-årsalderen fått langsomt økende skjevstillinger i flere fingerledd på begge hender. Senere ble det også påvist litt skjevt bitt. Røntgenundersøkelse før pri-

\section{Hovedbudskap}

- Trikorhinofalangealt syndrom kan oftest diagnostiseres klinisk

- Mest karakteristisk er tynn hårvekst, pæreformet nese med små nesevinger, langt philtrum, korte og krokete fingre, retardert høydevekst og kjegleformede epifyser ved røntgenundersøkelse

- Tilstanden skyldes mutasjon i genet TRPS1 og kan deles i tre typer

- Ved usikkerhet kan genetisk undersøkelse være aktuelt 
mærundersøkelsen viste kjegleformede epifyser i grunnfalangen på 1. finger bilateralt samt i midtfalangen på flere andre fingre.

Hennes mor, far og søster er friske. Foreldrene fortalte at hun ikke liknet på noen andre i familien. Det gikk svært lang tid før hun fikk hår på hodet som barn, og håret hadde alltid vært tynt og vokst langsomt.

Nesen var litt stor, pæreformet med bulbøs nesetipp og underutviklede alae nasi. Hun hadde langt philtrum og tynn overleppe. $\emptyset$ rene var normalt modulerte, men litt store og utstående. Håret var lyst og tynt uten krøller, og øyebrynene var litt tynne. Hun hadde normal lengde, normalt intellekt og normal utvikling for alderen. Det var normal karyotype 46,XX. Diagnosen trikorhinofalangealt syndrom type I ble stilt på bakgrunn av de kliniske funnene.

\section{Pasient 3 og 4}

To adopterte tvillingsøstre, oppvokst på barnehjem under svært sviktende forhold, ble $i$ 13-årsalderen henvist for "second opinion» pga. kortvoksthet og forsinket skjelettalder. Fødselsdatoen, og dermed alderen, var usikker. Høyden var henholdsvis $142 \mathrm{~cm}$ og $139 \mathrm{~cm}$, og menarketidspunkt (hhv. ett og fire år tidligere) og beinalder tilsa kun noen få $\mathrm{cm}$ igjen til slutthøyde. Begge hadde forsinket psykomotorisk utvikling, særlig pasient 3 som ble oppfattet utviklingsmessig til å være på 2-5-årsstadiet. Begge jentene hadde hørselstap. Pasient 3 fikk ved seksårsalderen diagnosen Calvé-Legg-Perthes sykdom. Pasient 4 hadde fått påvist sakralt spina bifida. Begge hadde veldig mobile ledd de første leveårene, hvilket ble mindre tydelig senere. Man antok lenge at deres forsinkede høydevekst og utvikling skyldtes omsorgssvikt de første leveårene.

Pasient 3 hadde tynt hår, kraftig nese med meget små nesevinger, antydning til retrognati, tynn overleppe, tynne øyebryn lateralt og deformerte fingre. Røntgen av hendene viste kjegleformede epifyser, spesielt proksimalt på midtfalangene. Hun hadde skjøre negler, liten plass til tennene, som var skjeve, men i normalt antall.

Pasient 4 hadde også tynt hår, et stort neseparti med meget små nesevinger og tynne øyebryn lateralt samt deformerte fingre (fig 2a), med kraftige ledd. Også her viste røntgen av hendene (fig $2 b$ ) kjegleformede epifyser. Hun hadde litt skjeve tenner i normalt antall samt skjøre negler.

De nevnte trekkene ble oppfattet som diagnostiske for trikorhinofalangealt syndrom, og klinisk var type 3 sannsynlig diagnose ettersom pasientene ikke har eksostoser og symptomene var mer uttalt enn ved type 1. Begge hadde normal, kvinnelig karyotype. Hos pasient 4 gjorde man genetisk undersøkelse og fant en partiell delesjon av TRPS1genet (ekson 1-4), forenlig med trikorhinofalangealt syndrom type 1. En så uttalt mental retardasjon som hos disse tvillingene er uvanlig ved type 1. Vi utførte derfor helgenomisk matriseundersøkelse for å undersøke om det forelå andre delesjoner eller duplikasjoner $i$ genomet som kunne forklare den mentale retardasjonen, men dette ble ikke funnet.

\section{Diskusjon}

I tabell 1 lister vi opp de vanligste kliniske trekkene ved trikorhinofalangealt syndrom og funn hos våre pasienter. Det fremgår at alle pasientene våre har tynn hårvekst, karakteristiske ansiktstrekk, endring på fingre, mens kun to har kort høydevekst. I tabell 2 presenteres de viktigste radiologiske funnene og ortopediske problemene ved syndromet samt tilsvarende funn hos våre pasienter.

To av pasientene våre ( $1 \circ \mathrm{og} 2)$ fikk diagnosen fastsatt på grunnlag av radiologiske og kliniske funn, mens for pasientene 3 og 4 var det nødvendig med genetisk undersøkelse for å avgjøre hvilken type pasientene hadde.

Ansiktstrekkene er karakteristiske og består av en stor, bulbøs nese med underutviklede nesevinger, langt philtrum med tynn overleppe, samt øyebryn som er tykke medialt og tynne lateralt. Typisk er også det tynne, ofte blonde, skjøre og langsomtvoksende håret samt kort lengdevekst. De fleste pasientene har dessuten mikrognati, og noen har utstående ører (4).

Utseendet er i mange tilfeller en belastning for disse pasientene, kanskje særlig for jentene, og mange får uønsket oppmerksomhet, spesielt pga. nesen. Siden syndromet er autosomalt nedarvet, burde det være like hyppig hos begge kjønn, men det er vist kvinnelig dominans, med en ratio på 1,7:1 i enkelte artikler (2), og alle våre fire pasienter er jenter. Kanskje skyldes dette at hårveksten (ofte omtalt som male pattern baldness) og de andre trekkene oppleves som mer belastende for jentene, slik at flere av dem oppsøker lege.

Trikorhinofalangealt syndrom er kjennetegnet ved en skjelettdysplasi som viser seg ved forsinket skjelettalder frem til pubertet, og deretter akselerert skjelettalder (2). Videre er hofteleddsplager vanlig ved syndromet og angis å forekomme hos mellom $50 \%$ (5) og mer enn $70 \%$ (2) av pasientene. Pasient 3 hadde fătt diagnosen Calvé-Legg-Perthes' sykdom, men dette er trolig en upresis diagnose. Hofteplagene ved trikorhinofalangealt syndrom er litt annerledes og har oftest et mer langtrukkent forløp (5).

En del har overtallige tenner eller jeksler som ikke bryter ut, og regelmessige tannhelsekontroller er derfor anbefalt. De har rett på fri tannbehandling. Det er beskrevet en rekke assosierte misdannelser $\mathrm{i}$ indre organer, som håndteres på vanlig måte for de respektive misdannelsene. Dette omfatter bl.a. vesikoureteral refluks og hydroureter, polycystiske ovarier, vaginalatresi og hemosalpinx samt en del medfødte hjertefeil (6). Dessuten er det vanlig med residiverende øvre luftveisinfeksjoner, særlig otitter.

Formaliserte diagnostiske kriterier for diagnosen trikorhinofalangealt syndrom er

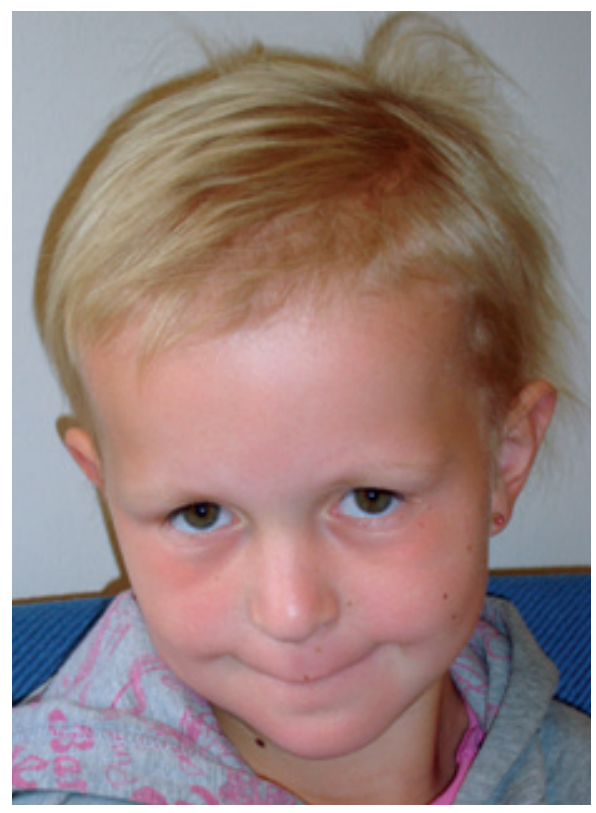

Figur 1 Pasient 1 har kort, tynt, lyst hår, sparsomme øyebryn, lett bulbøs nesetipp med små nesevinger og glatt, noe langt philtrum og tynn overleppe

ikke blitt definert, men de nevnte ansiktstrekkene, forsinket vekst, korte og krokete fingre (fra 5-6-årsalderen), og forandringer i negler (6) er så karakteristiske at klinikere og genetikere som har erfaring med tilstanden, kan stille en sikker diagnose. Særegne kjegleformede epifyser ses hos så godt som

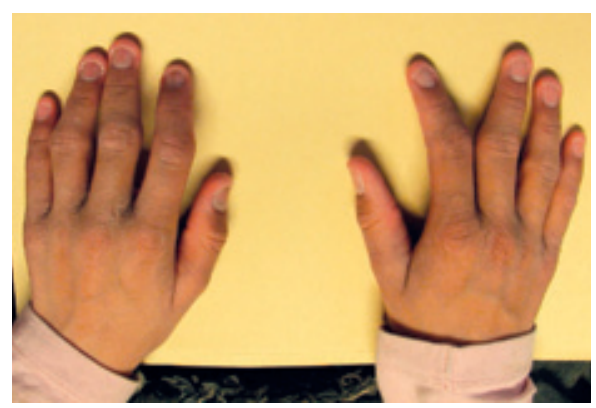

Figur 2a Pasient 4 har korte fingre, skjevstilling i flere proksimale interfalangeale (PIP) ledd, særlig på 2. finger, høyre hånd samt oppdrivning omkring flere ledd

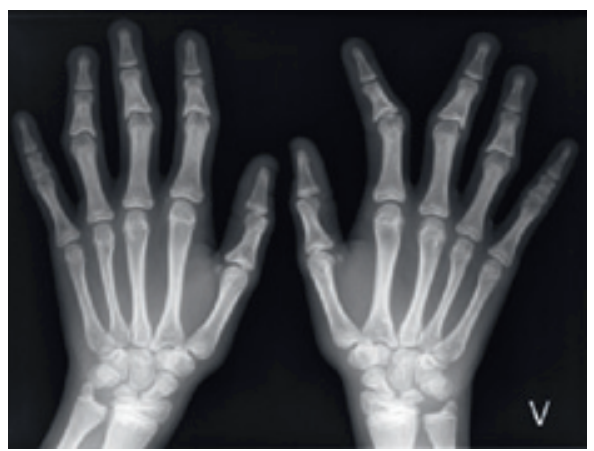

Figur 2b Røntgen av hendene til pasient 4 demonstrerer skjevstilling iflere ledd, særlig 2. finger, høyre hånd samt kjegleformede epifyser, som viser seg som bred basis på flere knokler, særlig midtfalangene. 
Tabell 1 Oversikt over de vanligste trekkene ved trikorhinofalangealt syndrom samt funn hos våre pasienter

Pasient 1 Pasient 2 Pasient 3 Pasient 4 Finnes ved type

\begin{tabular}{|c|c|c|c|c|c|}
\hline Alder ved diagnose & 5 år & 8,5 år & 13 år & 13 år & \\
\hline Tynn hårvekst & ++ & + & + & + & Alle typer \\
\hline Stor nese med små nesevinger & + & + & + & + & Alle typer \\
\hline Brakydaktyli & + & - & - & - & Alle typer \\
\hline Klinodaktyli/skjevstilte fingre & - & + & + & + & Alle typer \\
\hline Kortvoksthet & - & - & + & + & Alle typer \\
\hline Tynne øyebryn lateralt & + & - & + & $?$ & Alle typer \\
\hline Tynn overleppe & + & + & + & + & Alle typer \\
\hline Langt philtrum & + & + & \pm & + & Alle typer \\
\hline Retro-/mikrognati & + & - & + & + & Alle typer \\
\hline Utstående ører & $1+1$ & + & $1+1$ & $(+)$ & Alle typer \\
\hline Residiverende luftveisinfeksjoner & + & \pm & $?$ & $?$ & Alle typer \\
\hline Tannmisdannelser & - & $1+1$ & $1+1$ & $(+)$ & Type 1 og 3 \\
\hline Negleforandringer & + & - & + & + & Type 1 og 3 \\
\hline Eksostoser & - & - & - & - & Kun type 2 \\
\hline Hypermobile ledd & + & + & + & + & Særlig type 2 \\
\hline Mental retardasjon & - & - & ++ & + & Særlig type 2 \\
\hline Mikrocephalus & - & $?$ & $?$ & $?$ & Særlig type 2 \\
\hline Forsinket språk & - & $?$ & + & + & Særlig type 2 \\
\hline Løs hud i tidlig barndom & $1+1$ & $?$ & $?$ & $?$ & Særlig type 2 \\
\hline Mange nevi & - & $?$ & $?$ & $?$ & Særlig type 2 \\
\hline Høy gane & + & + & $?$ & ? & \\
\hline
\end{tabular}

alle med syndromet, og diagnosen er svært usannsynlig dersom man finner normale forhold ved røntgen av håndskjelett $(2,7)$.

Trikorhinofalangealt syndrom deles i tre typer. Tilstanden skyldes mutasjoner i genet TRPS1, som finnes på den lange armen til kromosom 8 (3). Det er påvist mer enn 35 forskjellige mutasjoner i TRPS1, som kan gi type 1 eller type 3 (OMIM \#190350 og OMIM \#190351) (8). Type 2 (OMIM \#190230) skyldes en større delesjon på 8q24.1, som i tillegg til TRPS1-genet minst inkluderer EXT1-genet og mellomliggende gener (9). Individer med denne typen har derfor en mer sammensatt og alvorlig fenotype, med mental retardasjon, mikrocephalus, overflødig hud og eksostoser (mangel på genproduktet til EXT1 gir eksostoser), i tillegg til de tidligere nevnte karakteristiske trekkene (10). Type 3 er den sjeldneste varianten og skiller seg fra type 1 ved mer uttalt brakydaktyli og kortvoksthet.

Genproduktet til TRPS1-genet regulerer uttrykking av flere andre gener. Det er et sinkfingerprotein som blant annet inneholder en DNA-bindende sekvens rettet mot motivet GATA $(3,11)$. Alle andre kjente GATAbindende proteiner er transkripsjonsfaktorer

Tabell 2 Oversikt over de radiologiske funn og ortopediske problemer man ser ved trikorhinofalangealt syndrom samt funn hos våre pasienter

\begin{tabular}{|c|c|c|c|c|}
\hline & Pasient 1 & Pasient 2 & Pasient 3 & Pasient 4 \\
\hline Kjegleformede epifyser ${ }^{1}$ & + & + & + & + \\
\hline Hypoplasi midtfalang (2./5.) & + & $(+)$ & ++ & ++ \\
\hline Hypoplastisk tommel & + & - & - & - \\
\hline Korte/tynne metakarper & - & $(+)$ & - & - \\
\hline Hoftedysplasi & $(+)$ & - & ++ & - \\
\hline Eksostoser ${ }^{2}$ & - & - & - & - \\
\hline Traktbryst & + & - & $?$ & $?$ \\
\hline Vingescapula & $?$ & $1+1$ & $?$ & $?$ \\
\hline Annen skjelettpatologi & Fotfeilstilling & Skjevt bitt & - & Spina bifida S1 \\
\hline
\end{tabular}

som øker transkripsjon, mens TRPS1 derimot virker transkripsjonshemmende (11). Den cellebiologiske effekten av denne transkripsjonshemningen er ikke fullt kartlagt, men mangel på TRPS1-protein ser ut til å øke aktiviteten $\mathrm{i}$ flere signalomformingsveier, bl.a. med forsinket differensiering av kondrocytter og raskere mineralisering av perikondriet til følge $(12,13)$.

Noen mutasjoner i TRPS1-genet gir ikkefungerende protein. Ettersom man da kun har én normal kopi av genet, medfører dette en halvering av mengden funksjonelt protein. Det ser ut til at tilstanden oppstår ved for lavt antall funksjonelle TRPS1-proteiner. Dette fenomenet kalles for haploinsuffisiens og er trolig årsaken til trikorhinofalangealt syndrom type 1 (2). Andre mutasjoner i TRPS1genet kan føre til danning av et protein som interfererer med funksjonen til det normale TRPS1-proteinet. Denne mekanismen kalles dominant negativ effekt. Slike mutasjoner er særlig blitt funnet hos pasienter med trikorhinofalangealt syndrom type $3(2,14)$, særlig i tilknytning til eksonet med den GATAbindende regionen. Det er sannsynlig at den dominant negative effekten forårsaker den mer alvorlige fenotypen ved type 3 (11).

Vanlig kromosomundersøkelse vil vise normale funn ved trikorhinofalangealt syndrom, bortsett fra noen tilfeller av type 2 (delesjonen må være $>5$ millioner basepar $(\mathrm{Mb})$ for å synes på karyotyping). Delesjonen ved type 2 er minst 2,8 Mb (9) og vil lett påvises ved fluorescent in situ-hybridisering (FISH) eller helgenomiske matriseundersøkelser. Ved mistanke om trikorhinofalangealt syndrom type 2 bør man først rekvirere vanlig kromosomanalyse, og dersom denne er normal, få utført helgenomisk matriseundersøkelse. Fullstendig søk etter mutasjoner i TRPS1-genet inkluderer sekvensering av DNA i tillegg til spesifikt å søke etter større delesjoner. Man har funnet mutasjon hos $86 \%$ av pasientene (2), men nevnte DNA-undersøkelser utføres ikke i Norge og reserveres vanligvis til tilfeller der man er i tvil om diagnosen.

Pasient 3 og 4 har en fenotype som er mer uttalt enn det man vanligvis ser ved trikorhinofalangealt syndrom type 1 . Deres mentale retardasjon kunne gi mistanke om type 2 , men de har ikke eksostoser, og genetiske analyser viser at delesjonen kun omfatter ekson 1-4 i TRPS1-genet. Ettersom tvillingene trolig er dizygote, er det sannsynlig at en av foreldrene deres også er affisert, men siden de er adopterte, har vi ingen opplysninger om dette.

Trikorhinofalangealt syndrom er autosomalt dominant arvelig og har komplett penetrans (2). Dermed er det $50 \%$ risiko for at barn av affiserte også får tilstanden. Mikrodelesjoner på 8q24.1 er nesten alltid nyoppståtte (de novo), slik at familiære former for trikorhinofalangealt syndrom type 2 i praksis ikke forekommer, i motsetning til ved type $1 \mathrm{og}$ type 3 . Hvis friske foreldre får 
flere barn med syndromet, kan det skyldes gonademosaikk, dvs. at en av foreldrene har mutasjon i en viss andel av cellene i gonadene, men ikke tilstrekkelig høy andel i annet vev til at de har symptomer på tilstanden (10). Det finnes ingen oversikt over hvor stor andel av mutasjonene i TRPS1-genet som har oppstått de novo. Ifølge data presentert av Lüdecke og medarbeidere (2) er det rimelig å anta at omtrent halvparten av tilfellene skyldes nyoppståtte mutasjoner, mens resten er nedarvet.

Hos enhver indeksperson bør man undersøke foreldrene for å se om de også har syndromet, slik at presis genetisk veiledning kan gis. Som med alle andre tilstander er det imidlertid en mulighet for overdiagnostikk. Ettersom symptomene kan være milde, vil nok enkelte personer leve et fullverdig liv med sitt trikorhinofalangeale syndrom uten å vite om at de har en slik tilstand. Ettersom det heller ikke finnes noen kausal behandling, kan det diskuteres om alle pasientene vil ha glede av å få diagnosen stilt.

Siden det ikke finnes kausal behandling av trikorhinofalangealt syndrom vil behandling og oppfølging rette seg mot å håndtere problemene som oppstår, særlig kosmetiske forhold og ortopediske problemer. Pasienter med type 1 og type 3, slik som pasient 1 og 2 , har normal intelligens, og mange er svært sjenert av sitt utseende. Plastikkirurgiske inngrep kan bli aktuelt, og flere personer med syndromet har fått utført slike operasjoner før diagnosen ble erkjent (15). Bruk av ringer blir vanskelig for noen pga. forandringer i fingrene. Tynn hårvekst er et kosmetisk problem for noen og kan også øke med alderen. Pasientene har rett til dekning av utgifter til tupé. Fertilitet og livslengde er ikke affisert ved type 1 eller 3 (16).

\section{Konklusjon}

Vi har her presentert fire pasienter med trikorhinofalangealt syndrom, der pasientene har ganske forskjellige grunner for kontakt med helsevesenet, men alle deler de sentrale trekkene ved diagnosen. Syndromet er trolig underdiagnostisert, og bedre kjennskap til diagnosen blant leger kan gjøre at flere får en diagnose og dermed en forklaring på livslange symptomer og plager samt at de kan få bedre oppfølging.
Det er gitt samtykke til publisering av pasienthistoriene og bildene.

\section{Kristoffer M. Brodwall (f. 1979)}

er assistentlege ved Barneklinikken, Haukeland universitetssykehus, men jobbet ved Barneavdelinga i Ålesund, Helse Sunnmøre da artikkelen ble skrevet.

Ingen oppgitte interessekonflikter.

\section{Pétur B. Júlíusson (f. 1964)}

er spesialist i barnesykdommer og er seksjonsoverlege ved Seksjon for endokrinologi og metabolisme, Barneklinikken, Haukeland universitetssykehus.

Ingen oppgitte interessekonflikter.

\section{Robert Bjerknes (f. 1958)}

er spesialist i barnesykdommer. Han er overlege ved Barneklinikken, Haukeland universitetssykehus og professor i barnesykdommer ved Universitetet i Bergen. Interessefelt er særlig barneendokrinologiske tilstander. Ingen oppgitte interessekonflikter.

\section{Randi Hovland (f. 1970)}

er dr.scient i molekylærbiologi og har de siste 12 årene jobbet ved Senter for medisinsk genetikk og molekylærmedisin, Haukeland universitetssykehus, med fagansvar for genetisk diagnostikk ved leukemi og kopitallsanalyser ved psykisk utviklinghemning. Hun har også en bistilling ved Molekylærbiologisk institutt, Universitetet i Bergen.

Ingen oppgitte interessekonflikter.

\section{Torunn Fiskerstrand (f. 1965)}

er spesialist i medisinsk genetikk og overlege ved Senter for medisinsk genetikk og molekylærmedisin og førsteamanuensis ved Institutt for klinisk medisin, Universitetet i Bergen. Ingen oppgitte interessekonflikter.

Litteratur

1. Giedion A Tricho-rhino-phalangeal syndrome. Helv Paediatr Acta 1966; 21: 475-85.

2. Lüdecke H-J, Schaper J, Meinecke P et al. Genotypic and phenotypic spectrum in tricho-rhinophalangeal syndrome types I and III. Am J Hum Genet 2001; 68: 81-91.

3. Momeni P, Glöckner G, Schmidt 0 et al. Mutations in a new gene, encoding a zinc-finger protein, cause tricho-rhino-phalangeal syndrome type I. Nat Genet 2000; 24: 71-4.
4. Niikawa N, Kamei T. The Sugio-Kajii syndrome, proposed tricho-rhino-phalangeal syndrome type III. Am J Med Genet 1986; 24: 759-60.

5. Dunbar JD, Sussman MD, Aiona MD. Hip pathology in the trichorhinophalangeal syndrome. J Pediatr Orthop 1995; 15: $381-5$

6. Lüdecke $\mathrm{H}-\mathrm{J}$, Horsthemke B. TRPS1 and the Tricho-rhino-phalangeal syndromes. I: Epstein CJ, Erickson RP. Wynshaw-Boris A, red. Inborn errors of development - the molecular basis of clinical disorders of morphogenesis. New York, NY: Oxford University Press USA, 2008: 1470-5

7. Giedion A. Phalangeal cone-shaped epiphyses of the hand: their natural history, diagnostic sensitivity, and specificity in cartilage hair hypoplasia and the trichorhinophalangeal syndromes I and II. Pediatr Radiol 1998; 28: 751-8.

8. Tariq M, Ahmad S, Ahmad W. A novel missense mutation in the TRPS1 gene underlies trichorhinophalangeal syndrome type III. Br J Dermatol 2008; 159: 476-8

9. Shanske AL, Patel A, Saukam S et al. Clinical and molecular characterization of a patient with Langer-Giedion syndrome and mosaic del(8)(q22.3q24.13). Am J Med Genet A 2008; 146A: 3211-6.

10. Gorlin R, Cohen M, Hennekam R. «Trichorhinophalangeal syndrome, type |» og «Trichorhinophalangeal syndrome, type II (Langer-Giedion syndrome)». Syndromes of the head and neck. 4. utg Oxford: Oxford University Press, 2001: 1005-8.

11. Malik TH, Shoichet SA, Latham P et al. Transcriptional repression and developmental functions of the atypical vertebrate GATA protein TRPS1. EMBO J 2001; 20: 1715-25

12. Suemoto H, Muragaki Y, Nishioka K et al. Trps1 regulates proliferation and apoptosis of chondrocytes through Stat3 signaling. Dev Biol 2007; 312 572-81.

13. Nishioka K, Itoh S, Suemoto H et al. Trps1 deficiency enlarges the proliferative zone of growth plate cartilage by upregulation of Pthrp. Bone 2008; 43: 64-71.

14. Hilton MJ, Sawyer JM, Gutiérrez L et al. Analysis of novel and recurrent mutations responsible for the tricho-rhino-phalangeal syndromes. J Hum Genet 2002; 47: 103-6.

15. Morioka D, Hosaka Y. Aesthetic and plastic surgery for trichorhinophalangeal syndrome. Aesthetic Plast Surg 2000; 24: 39-45.

16. Peltola J, Kuokkanen K. Tricho-rhino-phalangeal syndrome in five successive generations: Report on a family in Finland. Acta Derm Venereol 1978; 58: $65-8$

Mottatt 21.4. 2009, første revisjon innsendt 9.1. 2010, godkjent 28.4. 2011. Medisinsk redaktør Trine B. Haugen. 